\title{
TO NIE POJĘCIA WĘDRUJĄ, TYLKO KSIĄŻKI
}

\section{ROZMOWA Z DMITRIM LEVITINEM ${ }^{1}$}

Agata Łukomska i Michał Rogalski

Uniwersytet Warszawski

Agata Lukomska: Nasze pierwsze skojarzenie z XVII i XVIII wiekiem to Oświecenie. Ty natomiast próbujesz zdekonstruować idee Oświecenia jako wyraźnie określonego rozdziału bistorii idei. Czyżbyśmy mieli z. gruntu btedny obraz, tego okresu?

Dmitri Levitin: Wydaje mi się, że historycy dzielą się na tych, którzy dekonstruuja, i tych, którzy upraszczaja. Nie ma nic złego w uproszczeniach, ale nasz obraz XVII i XVIII wieku obrósł w mity, które niekoniecznie sa przydatne. Jednym z nich jest właśnie „Oświecenie” - w gruncie rzeczy pokantowskie, dziewiętnastowieczne pojęcie, projektowane wstecz na XVIII stulecie. Wszyscy zawodowi historycy zdaja sobie z tego sprawę i używają tego terminu na wiele różnych sposobów. Czasami jako poręcznego synonimu dla XVIII stulecia - w tym wypadku służy on po prostu chronologii i nie ma większego znaczenia. Nabiera go dopiero wtedy, gdy staje się nośnikiem jakiejś dodatkowej konceptualnej treści.

W 1935 roku Paul Hazard opublikowal słynną, nadal bardzo wpływową książkę Kryzys świadomości europejskiej 1680-1715 (Hazard 1974), w której umieścił wspaniała myśl, że w tamtym momencie swojej historii Europa zasnęła, myśląc jak Bossuet, i obudziła się, myśląc jak Voltaire. Podejrzewam, że rzeczywistość była bardziej skomplikowana. Pojawia się pytanie,

\footnotetext{
${ }^{1}$ Wywiad został przeprowadzony 25 października 2016 roku w Warszawie, gdzie Dmitri Leivitin odbierał Honorowe Stypendium im. Leszka Kołakowskiego. Fundacja na rzecz Nauki Polskiej wyróżnia nim szczególne osiagnnięcia młodych uczonych w zakresie historii idei, filozofii średniowiecznej i nowożytnej do 1939 roku [przyp. red.].
} 
co właściwie znaczy, że była „skomplikowana”? Tradycyjna opowieść szczególną rolę przyznaje filozofii. Zgodnie z tą opowieścią w pewnym momencie pojawił się Kartezjusz albo, w nowszej, modnej teraz wersji tej opowieści, Spinoza, albo - w wariancie angielskim - Locke czy Newton, i to zmieniło wszystko: dokonała się emancypacja Rozumu. Im głębiej jednak studiujemy historię XVII i XVIII wieku, tym bardziej zaczynamy sobie zdawać sprawę z tego, że filozofia tego okresu, choć pasjonująca, ważna i warta studiowania, nie jest kluczem do wyjaśnienia wszystkiego. Okazuje się bowiem, że można było być kartezjaninem i zarazem całkowicie ortodoksyjnym kalwińskim teologiem, że w Anglii można było jednocześnie głosić teorie Newtona i sympatyzować z torysami, sprzeciwiając się tolerancji religijnej, i tak dalej. Dla mnie to kluczowa sprawa: Oświecenie, ilekroć ten termin ma jakąś treść, implikuje związek między szeroko rozumianą postępową polityką, choćby polityką tolerancji religijnej, oraz postępowymi ideami. Zmiany polityczne, o których mówimy, się dokonały, co do tego nie ma watpliwości. Mnie interesuje jednak przede wszystkim, czy istnieje bezpośredni związek między tym, co działo się wówczas w polityce, a tym, co dokonywało się w sferze intelektualnej. Przecież nie brakowało wówczas niezwykle śmiałych intelektualistów, którzy jednocześnie byli, szczerze mówiąc, bigotami i okropnymi ludźmi albo po prostu bezmyślnie ortodoksyjnymi chrześcijanami. Takie są fakty historyczne i nie możemy ich ignorować. Tym, co mnie szczególnie frapuje, jest właśnie ten brak ciągłości między polityką a ideami. Choć mam nadzieję, że mówię tu coś nowego, ten wątek pojawiał się już w badaniach nad historią angielskiej nauki w Royal Society. W latach 70. i 80. ubiegłego wieku skłaniano się do wyjaśnienia politycznego, twierdząc, że wszyscy członkowie tego towarzystwa byli purytanami czy anglikanami. Późniejsze badania prozopograficzne wykazały jednak, że wśród członków Royal Society byli i druidzi, i katolicy. Nie brakowało też ludzi, którzy wychodzili poza jakąkolwiek ortodoksję. Autorstwa zmiany intelektualnej nie da się zatem przypisać jednej grupie politycznej lub religijnej.

\section{AL: Jeśli ratem nie filozofia, to co uksztattowato XVII wiek? Cqy pojawit sie jakis jeden zupetnie nowy czynnik, który umo:̀iliwit to, co nazwateś ,intelektualna zmiana"?}

DL: Nie, nie ma czegoś takiego, co definiowałoby XVII wiek. To w pewnym sensie moje najważniejsze odkrycie. Zarazem jednak chciałbym wskazać na kilka czynników, o których mówi się niewiele ze względu na

\section{/ 114 STANRZECZY 1[10]/2016}


dominującą rolę koncepcji Oświecenia i unaukowienia. Jednym z nich jest coś, co możemy określić mianem „późnego humanizmu” czy też „późnego renesansu". Wszyscy wiemy o tym, że renesans polegał na powrocie do klasycznego antyku, najpierw we Włoszech w XIV i XV wieku, a później w innych regionach Europy. Zdecydowanie mniej wiemy za to, a przynajmniej do niedawna wiedzieliśmy zdecydowanie mniej, o dalszych losach tego ruchu w drugiej połowie XVI wieku i w wieku XVII. Jak już mówiłem, tradycyjna opowieść była taka, że pojawił się Kartezjusz czy Bacon i ludzie po prostu przestali interesować się przeszłością. Oczywiście wierzyliśmy w to nie bez powodu - przede wszystkim uwierzyliśmy ich własnej, to jest Kartezjusza i Bacona, retoryce. Kartezjusz pisze przecież, że uwolnił swój umysł od wpływu autorytetów, zaczął od zera. Także Bacon wzywał do ich odrzucenia. Kiedy ktoś twierdzi, że coś robi, to jesteśmy skłonni mu wierzyć.

Jedną z największych zmian, jakie zaszły w historiografii w ostatnich trzydziestu, czterdziestu latach, jest to, że przestaliśmy wierzyć ludziom na słowo. Zamiast tego sprawdzamy, co faktycznie robili; badamy ich rękopisy, studiujemy książki, które napisali, ustalamy, co czytali, wydobywamy na światło dzienne nie tylko rezultaty ich działań, lecz także same działania.

Michał Rogalski: To oznacza skupienie sie na problemie recepcji, który, co tu kryć, nie jest zbyt sexy.

DL: (śmiech) Jak najbardziej.

MR: Co ma w Twojej pracy pierwszeństwo: poszukiwanie w kulturze ciaglości, śledzenie recepcji cay raczej wypatrywanie nowości?

DL: Jak by to ująć - pytanie o ciągłość i zmianę jest tak stare jak sama historia; zawsze mamy nadzieję rozpoznać prawdziwą zmianę, kiedy ma miejsce, i podkreślamy ciagłość, gdy o prawdziwej zmianie nie może być mowy. Ale łatwo tu o nadużycia. Użyłeś określenia sexy i coś w tym jest: usprawiedliwiamy wiele z tego, co robimy - albo robią to wydawcy, którzy chcą sprzedać nasze ksiażki - ogłaszając wielkie przełomy i radykalne zerwania $z$ tradycja. Ten zabieg jest szczególnie popularny w anglojęzycznej historiografii, gdzie panuje swoisty kult eleganckiego pisarstwa i kult argumentowania, przeciwstawianego prezentowaniu „suchych” danych. Najłatwiej jest powiedzieć: no cóż, wszyscy sądzili, że było tak i tak, aż tu nagle pojawiłem się ja, i zmieniłem wszystko. To jest niesamowicie pocią- 
gające. Tak, świadomie odchodzę od tego modelu, bo zdaję sobie sprawę z ukrytych w nim pokus. Nie znaczy to jednak, że nie próbuję nadać swojemu tematowi jakiejś struktury, nie wprowadzam przydatnych w moim odczuciu kategorii; jedną z nich jest właśnie późny humanizm. Pod koniec XVI wieku zaszła pewna rzeczywista zmiana, dzięki ludziom takim jak Joseph Scaliger czy Isaac Casaubon (podpieram się tu badaniami wybitnego amerykańskiego historyka Anthony'ego Graftona: 1983, 1990, 1991, 1997, 2011a, 2001b). Byli oni tradycjonalistami o tyle, o ile ich praktyki były zakotwiczone w typowo renesansowych umiejętnościach, takich jak studia filologiczne i krytyczna lektura klasycznych tekstów. Z tym tylko, że opanowali oni te tradycyjne umiejętności w tak wysokim stopniu, że pojawiło się w nich poczucie dystansu. W efekcie przeszłość przestała być dla nich modelem do naśladowania, a stała się czymś, co domaga się wyjaśnienia. W ten sposób dokonało się coś, co moglibyśmy (choć ja niekoniecznie) nazwać intelektualną rewolucją, ale taka, która wydarza się w obrębie tradycyjnych struktur wiedzy - rewolucją, którą nie kierują outsiderzy, ,seksowni” heterodoksyjni myśliciele. Podejrzewam, że to jest bardzo angielskie ujęcie oparte na kulcie najsłabszego gracza, który wbrew wszelkim prognozom strzela gola na Wembley i zdobywa dla swojej drużyny Puchar Świata. Mnóstwo ludzi pisze historię w ten właśnie sposób, bo jest to kuszące. Często jednak procesy, które się dokonywały, by tak rzec, w mainstreamie, były równie rewolucyjne.

MR: Mogłoby sie wydawać, że badanie ciagtości tradycji polega przede wszystkim na śledzeniu tego, w jaki sposób ludzৃie nadaja pojeciom nowe znaczenia, zwtaszcza jesli mówimy o tradycjach w historii filozofii cay tradycjach religijnych, pod wplywem których pozostawali ci siedemnastowieczni myśliciele. Jakie czelkaja nas tu niespodzianki?

DL: To ciekawe, że przywołałeś termin „pojęcie”. Nie nazwałbym się historykiem pojęć. Powiedziałbym raczej, że badam historię książek, nie tylko jako nośników myśli, ale wręcz jako fizycznych przedmiotów. $\mathrm{Na}$ przykład, pracowałem w Trinity College w Cambridge, gdzie mieliśmy bibliotekę Izaaka Newtona, to znaczy znaczną część tego, co się z niej zachowało. Okazuje się, że Newton miał zwyczaj zaginać rogi stron, żeby zaznaczyć fragmenty, które go interesowały. Dzięki temu można bardzo łatwo ustalić, co czytał. 


\section{AL: To takie namacalne!}

DL: Właśnie tak! To nie jakaś podniebna sfera pojęć, to prawdziwy człowiek, który kupował książki. Newton czasem notował wręcz na pierwszej stronie: „Kupione za 12 szylingów, 1679”. Dzięki Tony’emu Graftonowi i kolejnym badaczom zrozumieliśmy, że nie można poprzestać na studiowaniu pojęć czy idei, jak to robiono do połowy XX wieku. Jesteśmy w stanie, przynajmniej czasami, odtworzyć naszych bohaterów przy pracy. A wtedy nie możemy się oprzeć wrażeniu, że obserwujemy stale rozwijającą się tradycję. Dowiadujesz się np., że Newton miał własny egzemplarz pism Ojców Kościoła, wydrukowany w Paryżu w latach 30. XVII wieku - skąd go wziął? Odkrywasz, że to była lektura w Cambridge, jedna z tych książek, których nabycie polecano studentom. Zaczynasz dociekać, jak ten konkretny egzemplarz trafił do Cambridge czy Londynu, gdzie Newton go kupił? I wkraczasz w zupełnie nowy świat historii jednej książki. Tak naprawdę nigdy nie obracasz się wyłącznie w sferze idei czy pojęć.

MR: Dla mnie - bistoryka polskiej filozofii - to, o czym mówisz, brzmi jak piekny sen. W Europie Środkowej $i$ Wschodniej rzadko mamy luksus takiej pracy

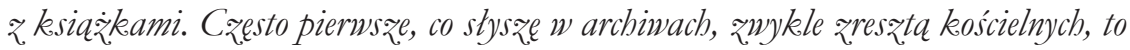
że okereślony materiat źródtowy nie istnieje: przę bolszenvikón, II wojne światowa czy inne wydarzenia XX wieku.

AL: W pewnym sensie sprzyja to badaniu historii samych pojeć- skoro nie masz. dostęu do ksiażek...

DL: Dotknęliście bardzo interesującej kwestii. W wypadku fizycznej destrukcji nie da się nic poradzić. Problem braku znajomości oryginału miewa jednak też inną, dużo bardziej banalną, ale pewnie nie mniej istotną, postać. W Kalifornii i Australii pracują świetni historycy filozofii i historycy idei, którzy jednak, z dala od Europy, mają trudności z dotarciem do materiałów źródłowych. Jakimś rozwiązaniem jest Internet; wielkim przedsięwzięciem jest obecnie digitalizacja nie tylko drukowanych książek, ale też dawnych rękopisów. Dam Wam jeszcze jeden przykład ze środowiska badaczy Newtona: The Newton Project, którego współrealizatorami są Scott Mandelbrote i Rob Iliffe z Oksfordu, daje dostęp do ponad sześciu milionów słów z rękopisów Newtona, z których większość znajduje się w Jerozolimie. Ta historia jest fascynująca sama w sobie...

Chodzi o rękopisy poświęcone w większości tematyce religijnej. W latach 30. XX wieku, kiedy pewien prywatny kolekcjoner wystawił je na 
sprzedaż, nikt nie chciał ich kupić. Einstein próbował przekonać do zakupu kilka amerykańskich uniwersytetów, ale bez skutku. W czasie Wielkiego Kryzysu nikt nie chciał wydawać pieniędzy na takie rzeczy... Ostatecznie zbiór kupił żydowski kolekcjoner Abraham Yahuda. Po jego śmierci manuskrypty trafily do Biblioteki Narodowej Izraela i wszyscy o nich zapomnieli do lat 70., gdy pojawiła się ekipa w stylu, nie przesadzam, Indiany Jonesa, i oto teraz mamy do dyspozycji tysiące stron niezbadanych dotąd rękopisów Newtona. Zostały one nie tylko zdigitalizowane, ale też przetranskrybowane, bo pełno w nich było skreśleń, fragmentów po łacinie, po grecku i hebrajsku. The Newton Project nie byłby możliwy trzydzieści czy czterdzieści lat temu (mówimy tu o stu, może dwustu tomach, kto coś takiego wydrukuje, nawet kiedy chodzi o Newtona!), a teraz, po części dzięki tej inicjatywie, pierwszorzędne badania nad Newtonem prowadzi się w Nowej Zelandii.

AL: Wrócmy do wcreśniejszego watku, powiedziałeś, że intelektualne zmiany dokonuja sie crasami odśrodkowo, drięki ludziom, którzy zgromadzili tak wielkea wiedze, że byli w stanie stworzyć nowe podejscie czy wrecz nowy paradygmat.

DL: Mocno wierzę w historię jako dyscyplinę kumulatywną. Chętnie posługujemy się kategoriami, takimi jak rewolucja, ewolucja paradygmatów czy innymi „odkryciami Ameryki”. Badania historyczne polegaja jednak w pierwszej kolejności po prostu na gromadzeniu odpowiedniej liczby świadectw. Oczywiście, jeśli nazbierasz świadectw nieinteresujących albo nieistotnych, albo nie umiesz ich zinterpretować, nic ci to nie da. Ale bez wątpienia w tym, co robię, jest coś kwantytatywnego, co można oczywiście również uznać za wadę. Najbardziej interesują mnie kwestie sytuowania zmian intelektualnych w czasie i rekonstruowania tego, jak ludzie naprawde myśleli. Odpowiadając na pytania o Oświecenie, rewolucję naukową czy Renesans, musimy się odważyć zanurkować pod powierzchnię faktów.

AL: Nie zniechęca Cie swwiadomość, ze wiekeszosíc twoich potencjalnych czytelników po prostu nie jest do tego preygotowana?

DL: No cóż, nie widzę powodu, dlaczego kiedy skończymy naszą pracę, nie mielibyśmy wyjaśnić wyników zainteresowanym czytelnikom. Niebezpieczne jest raczej, wydaje mi się, stawianie sprawy na głowie, to znaczy sytuacja, gdy zaczynasz jakiś projekt z założeniem, że to będzie przeznaczone dla szerokiej publiczności albo dla tego, co sobie wyobrażamy jako

\section{/ 118 STANRZECZY 1[10]/2016}


szeroką publiczność... W pisaniu pamiętanie o potrzebach czytelnika jest równie ważne jak forma literacka. Tak bardzo, jak oparta na faktach narracja mi na to pozwala, staram się pisać prosto. Mnóstwo prac z zakresu humanistyki pisze się niepotrzebnym pseudonaukowym żargonem, zniechęcającym zarówno laików, jak i specjalistów, i tym sposobem zostajemy bez żadnych czytelników. Raczej nie idę na kompromisy, jeśli chodzi o złożoność narracji, ale staram się, na miarę moich literackich zdolności, uczynić każde zdanie i każdy paragraf, i każdą stronę tak zrozumiałymi, jak to tylko możliwe.

AL: Mamy chyba sketonnośc myśléc, ze z.problemami w kontekśsie przekazywania wiedzy musimy sie mier yyć dzisiaj, podcras gdy dawniej nauke uprawiano w sposób rygorystyczny. Ale to przecież nie może być prawda. Wyobrażam sobie, że Renesans byt mo:zliwy miedzy innymi dlatego, że dysponowat wlasnymi technikami upraszczania i mitologizacji.

DL: Jak najbardziej.

AL: Więc może fakt, że zmagamy sie z podobnymi problemami, może nam pomóc rozszyfrowaí dawne teksty?

DL: To jest doskonałe pytanie i cieszę się, że padło. Jednym z mniej znanych faktów na temat XVI i XVII stulecia jest to, że była to epoka uniwersytetów - porównywalnie dobrze będa się one miały dopiero w połowie XX wieku. Na przykład w Anglii i na kontynencie procent ludności, dla której było to w ogóle możliwe - to znaczy dorosłych mężczyzn odbierających wykształcenie uniwersyteckie - był od połowy XVI do końca XVII wieku wyższy niż kiedykolwiek później aż do połowy XX wieku. Dla większości ludzi to zaskakująca wiadomość - stereotyp głosi, że uniwersytety wtedy skostniały, popadły w sztywną pedanterię, zamieniły się w instytucjonalne ośrodki nudy, gdzie studiowano łacińskie teksty albo w kółko czytano Arystotelesa, bez jakichkolwiek nowych pomysłów. Tymczasem okazuje się, że były to czasy niesamowitego skoku naprzód, jeśli chodzi o szkolnictwo wyższe, ale też społeczną mobilność! Uniwersytety nie były zarezerwowane dla elit. Członkowie arystokracji wstępowali na uniwersytety, ale mało kto z tych kręgów kończył studia, był to dla nich rodzaj rozrywki. Celem większości studentów było uzyskanie stopnia zawodowego lub naukowego, żeby móc zostać teologiem, prawnikiem czy lekarzem. W Anglii z reguły było tak, że zdolnego chłopca zauważał wiej- 
ski nauczyciel, może proboszcz, który posyłał go na uniwersytet po to, by potem wrócił i nauczał w swojej parafii. To był bardzo skuteczny system rekrutowania ludzi z prowincji, kształcenia ich i późniejszego szerzenia za ich pośrednictwem wiedzy w społeczeństwie. Dlatego myślę, że historia uniwersytetów i mechanizmów, jakie one wykształciły, by edukować tę bezprecedensowo wielką kohortę, pozostaje całkowicie niedocenianym czynnikiem kształtującym XVI i XVII wiek. Jeśli chodzi o kulturę uniwersytecka, pionierskie badania prowadzi Mordechai Feingold z CalTech w Kalifornii. Mamy wystarczająco dużo świadectw, by odrzucić tradycyjna opowieść i uznać, że rewolucja naukowa, jeśli nadal chcemy to tak nazywać, nie przyszła spoza uniwersytetów, ale z ich wnętrza. By odwołać się do wspomnianego już przykładu Royal Society - jego założyciele poznali się w Oksfordzie w latach 40. i 50. XVII wieku.

MR: Piszesz, że miało to zwiqzele ze warostem zainteresowania historia, który nazywasz zwrotem historycznym. Przypominas₹, ze to wtasnie uniwersytet byt miejscem, w którym przechowywano dawne teksty, stare ksią̇ki.

DL: Kwestia dostępu do materiałów źródłowych leży w samym centrum mojej pracy. Weźmy za przykład spory religijne i uświadomienie sobie historycznego charakteru zjawisk religijnych. Upowszechnienie się przekonania, że Biblię należy czytać w kontekście; że należy poddać krytycznym studiom związki między chrześcijaństwem a hellenistycznym czy międzytestamentalnym judaizmem i pogaństwem, czy tym, co siedemnastowieczni uczeni nazwaliby pogaństwem. I znów, według tradycyjnej opowieści ludzie byli pobożnymi prostaczkami aż do czasów Spinozy, który wynalazł to wszystko, bo był radykałem i myślał w sposób niezależny. Kto miał jednak materiały, środki i motywację, by uczyć się hebrajskiego czy arabskiego, kupować książki, kupować czcionki? Trzeba pamiętać, że książek w tym okresie drukuje się już dużo, ale nadal nie jest to łatwe. Jeśli chcesz wydrukować książkę z fragmentami po arabsku, musisz wykonać odpowiednią czcionkę, a ponieważ pismo arabskie zawiera ligatury, to taka czcionka jest trudna do wykonania, musisz znaleźć kogoś, kto się na tym zna. Kto ci kogoś takiego znajdzie? No cóż, zapewne Kościół, ponieważ dysponował kontaktami na Wschodzie. Tymczasem anglosascy badacze przyzwyczaili się traktować przedsoborowy katolicyzm jako coś w rodzaju zapowiedzi dwudziestowiecznych totalitaryzmów. Ale XVII-wieczni intelektualiści nie mieli takich uprzedzeń. I tak na przykład Rzym był wówczas centrum studiów orientalnych, ponieważ sprowadzał maroni- 
tów i mówiących po arabsku chrześcijan z Afryki Północnej, którzy uczyli języka arabskiego, wykonywali czcionki i opracowywali książki. Poza tym Kościół rzymskokatolicki miał przyjaciół we Francji, w Anglii, nawet w luterańskich Niemczech. Dlaczego? Z powodu swego rodzaju międzywyznaniowej zimnej wojny. Pisano i drukowano wówczas książki głównie po to, by się nimi nawzajem okładać po głowie. Ta myśl jest oczywiście mało popularna. Wolimy wyjaśniać intelektualny postęp jako sumę osiagnięć dobrych ludzi, pacyfistów i zwolenników tolerancji. Myślę jednak, że pisanie historii intelektualnych przemian polegających na uświadamianiu sobie historycznego charakteru zjawisk religijnych w XVII wieku w taki sposób, by jej bohaterami byli sympatyczni ludzie, przypominałoby pisanie historii wyścigu kosmicznego, gdzie w rolach głównych nie występowałyby USA i ZSSR, ale miłe, pokojowo nastawione kraje w rodzaju Holandii i Szkocji. Sam jestem ze Szkocji i byłbym zachwycony, gdyby to była prawda. Jest jednak inaczej.

Wojna jest okazją do inwestycji i dostarcza bodźców dla niektórych form intelektualnej aktywności. Oczywiście zarazem tę aktywność ogranicza. A zadaniem historyka jest ustalenie, gdzie stworzyła szanse, a gdzie ograniczenia. Analizowanie konfliktu między intelektualistami jest dla mnie o wiele bardziej interesujące i stymulujące niż model przeciwstawiający sobie konserwatywnych idiotów i postępowych outsiderów.

Tłum.: Agata Lukomska

Bibliografia:

/// Hazard P. 1974. Kryzys świadomości europejskiej 1680-1715, tłum. J. Lalewicz, A. Siemek, wstęp M. Żurowski, Państwowy Instytut Wydawniczy.

/// Grafton A. 1983. Joseph Scaliger: A Study in the History of Classical Scholarship, Clarendon Press.

/// Grafton A. 1990. Forgers and Critics. Creativity and Duplicity in Western Scholarship, Collins \& Brown.

/// Grafton A. 1991. Defenders of the Text: The Traditions of Scholarship in the Age of Science, 1450-1800, Harvard University Press.

/// Grafton A. 1997. Commerce with the Classics: Ancient Books and Renaissance Readers, University of Michigan. 
/// Grafton A. 2011a. The Culture of Correction in Renaissance Europe, The British Library.

/// Grafton A. 2011b. "I have always loved the Holy Tongue": Isaac Casaubon, the Jews, and a Forgotten Chapter in Renaissance Scholarship, Belknap Press of Harvard University Press. 